\title{
Voices of English Teachers and Students on Blended Culture as a Model of English Language Teaching and Learning at Vocational High Schools in Yogyakarta
}

\author{
Margana Margana
}

\author{
English Education Department, Faculty of Languages and Arts, State University of Yogyakarta, Yogyakarta, Indonesia
} margana@uny.ac.id

\author{
Doi:10.5901/mjss.2016.v7n3p459
}

\section{Abstract}

\begin{abstract}
This study deals with the voices of English teachers and their students on the use of blended culture as a model of English language teaching at vocational high schools in Yogyakarta, Indonesia. It primarily aims at describing the voices of the utilisation of blended culture and documenting the difficulties encountered by English teachers and their students. To obtain the objectives, the researcher invited 20 English teachers and 300 students from 9 vocational high schools in Yogyakarta to be involved in this study on voluntary bases. The research instruments were questionnaires, observation sheets, and interview guides. To back up the data collection, the researcher provided video recording. The data were analysed by using descriptive qualitative techniques. Research findings are as follows. First, most of the English teachers of vocational high schools tend to focus more on the development of microskills (grammar, vocabulary, and pronunciation) than on the macroskills of English: listening, speaking, reading, and writing. Second, most English teachers state that they have not been familiar with the model of blended culture used in the process of English language teaching and learning (ELTL). This is supported by students' responses during the interviews, reporting that their English teachers do not highlight the incorporation of target and local culture in the process of ELTL. Third, teachers show strong supports for the utilisation of blended culture as a model of ELTL at vocational high schools. Fourth, efforts are needed for designing lessons that incorporate blended culture and importing local and target culture into the textbooks in the teaching of English at vocational high schools. In summary, blended culture has to be applied in the process of ELTL because blended culture represents the use of language according to the contexts to facilitate students to maximally acquire the target language.
\end{abstract}

Keywords: blended culture, local culture, target culture, teaching English language teaching and learning

\section{Introduction}

The import of cultures (home or local culture and target culture) in the process of English language teaching and learning (ELTL) at any level of education including secondary schools becomes the concern of a number of scholars (Byram, 1989, 1994a, 1994b, 1997a, 1997b; Kramsch, 1988, 1993, 1996, 2001; Friedrich, 1989; Stuart \& Nocon, 1996; Sysoyev \& Donelson, 2002; Crozet \& Liddicoat, 2000; Liddicoat et al., 2003; Mitchell \& Myles, 2004; Lambropoulos \& Christopoulou, 2004; Risager, 2005; Çelik, 2005; Papademetre \& Scarino, 2006; Brown, 2007; Ho, 2009; Sugirin et al., 2011; Siddiqie, 2011; Margana, 2009, 2013, 2015; Sukarno, 2012). It is agreed that English teachers should import home culture and target culture in the process of ELTL, primarily aimed at establishing the intercultural awareness of students enabling them to enhance their understanding of the second language (hereafter L2), develop their sensitivity of using L2, and promote flexibility and tolerance in their encounter with cultural diversities. Such awareness is highly required in global life contexts in order to prevent and minimise possible conflicts emerging in cultural differences. This suggests that the incorporation of cultures in pedagogical activities in ELTL at any level of education should be taken into account to make students able to capture the comprehensive understanding of how the target language really works within the student's home culture. In other words, the import of the home culture and target culture in pedagogical activities at schools has to be conducted to facilitate students to maximally acquire the target language. This includes ELTL in the vocational high schools (hereafter VHS).

The embedment of cultures in ELTL is based on the statement that studying L2 without knowing anything about how people use L2 in some communicative events seems senseless, inaccurate, and incomplete (Bada and Genc, 2005). Further, they strongly claim that the teaching of L2 is not merely a matter of the manipulation of the $\mathrm{L} 2$ grammar and vocabulary. In the same spirit, Williams (2011) states that learning the target language is not only concerned with forms and meanings of the language learned but also with the use of the L2 in some social contexts of the society of the target language. This means that L2 students have to be guided to further reveal how culture inspires the use of language in 
context because language and culture are intertwined in nature. This suggests that, to maximally acquire the target language, students should understand the essence of how language works in the social contexts of the native speakers of the target culture (Margana, 2015). This is in line with the statement that language is a social possession, not an individual one (Wardhaugh, 2006).

In relation to the principles above, teaching English at the VHS should not be directed only on the forms of grammar and vocabulary. Students of VHS should have some knowledge of how English works in some social contexts of the target culture. Added to this, VHS students should be equipped with experiences of how English is used in communication practices in connection with their study backgrounds of secretariat, accounting, management, culinary, tourism, engineering, crafts and arts, and other study backgrounds. This facilitates the students to clearly conceptualise and contextualise the use of English in the appropriate contexts of various workplaces after they finish their vocational education.

From the observation conducted as the initial stage of the study, a great number of the VHS English teachers tend to focus their emphasis on language forms (systemic knowledge) in their ELTL classes which accentuate on the elements of language. Their common classroom practices done by English teachers at vocational high schools in Yogyakarta merely give an emphasis on pronouncing words through drilling techniques; teaching separate vocabulary items and conversational gambits; explaining English grammar in isolation; and imposing students to complete student worksheets which focus on answering comprehension questions, grammar problems, and vocabulary exercises.

The conditions above are also evident from the teachers' lesson plans in which emphasis is put on the attainment of systemic knowledge such as parts of speech, subject-verb agreement, passive voices, conditional sentences, and the like. It is true that, in the lesson plan, the English teachers use various texts as required in the curriculum. However, in the process of making sense of the texts, they tend to ignore the analysis of cultural aspects. Instructional activities are dominated by answering comprehension questions of reading texts followed by isolated explanation of grammar and translation practices from English to Indonesian or vice versa. Most English teachers of VHS rarely provide students with problems and issues of the target and local culture to be discussed in the class. If there is a discussion on culture, it does not touch the principle of the importance of the cultural aspects of instruction.

The import of home and target culture into the curricula is expected to facilitate students to understand how the target language works in social practices and to assist them to store the experiences in the long-term memory in constructing their schematic knowledge which enables them to recall any time when they encounter any linguistics and cross-cultural barriers. Chastain (1988: 303) strongly advocates the principle that the import of culture in the process of ELTL directly contributes students' ability to deal with the function of language in terms of linguistics and social issues. In other words, the inclusion of local culture and target culture in the curriculum, methodology, and teaching materials of ELTL would make learning easier and more meaningful for L2 learners. To summarise, the incorporation of culture in the pedagogical practices at VHS is necessary in order to facilitate students to lateralise the L2 so that they could make use of it in any communicative contexts.

In reference to the above issues, this paper attempts to describe the voices of the utilisation of blended culture and document the difficulties which are likely encountered by English teachers and their students when the blended culture model is implemented in the process of English language teaching and learning at vocational high schools in Yogyakarta in particular and other secondary school levels in general.

\section{Literature Review}

This section deals with the exploration of home culture and target culture to justify the importance of blended culture model in ELTL. It mailny discusses some issues: theoritical justification of the import of culture in ELTL and nature of blended culture. Each is presented below.

\subsection{Theoritical Justification of the Import of Culture in ELTL}

Since the 20th century the incorporation of the target culture and local culture in the process of English language teaching and learning has become a concern for a number of scholars (Gonzalez, 1995; Davis, 1996; Kirl, 2001; Fengyan, 2002; Liddicoat, 2002; Peterson \& Coltrane, 2003; Trumbull \& Rothsten-Fish, 2009; Sugirin et al., 2011; Margana, 2009, 2013, 2015; Sukarno, 2012). They have come to the agreement that culture should be incorporated in the process of English language teaching and learning on the grounds that the embedment of the two cultures facilitates students to maximally acquire the target language (Byram, 1989; 1994a; 1994b; 1997a; 1997b; Kramsch, 1988; 1993; 1996; 2001; Sysoyev \& Donelson, 2002; Margana, 2015). Krasner (1999), who strongly urged that L2 learners should be concerned with 
linguistic competence and socio-cultural competence if they wish to be competent in the target language, supported this statement. This implies that L2 learners need to be aware of how to select appropriate phrases for addressing people, greeting someone, thanking, complementing, making requests, telephoning, and others that are part of the social contexts.

Hedge (2008) quoted in Margana (2012) strongly advocates that L2 learners should activate two types of knowledge, namely systemic and schematic. The former refers to the knowledge about language while the latter deals with knowledge beyond the language one of which is socio-cultural knowledge (how language is used in the social contexts). Further, Margana (2015) urges that with the use of socio-cultural knowledge L2 learners are able to reveal the inner layer of language in the sense that they could capture how language is contextually applied in the real communication practices as performed by society members. Bachman (1990) quoted in Johnson (2004) uses the term sociolinguistic competence that embodies the socio-cultural knowledge. According to him, this competence is part of pragmatic competence that refers to the abilities to make sense of language varieties and cultural differences and figures of speech. The term sociolinguistic competence is also proposed by other scholars such as Canale \& Swain (1980) and Hymes (1972) as quoted in Johnson (2004). According to them, L2 learners have to achieve sociolinguistics competence that qualifies the interrelation between language and culture, making students acquire the target language successfully.

In support of the above statements, a number of scholars strongly claim that language and culture are interwoven in nature (Byram, 1989; 1994a; 1994b; 1997a; 1997b; Kramsch, 1988; 1993; 1996; 2001; Sysoyev \& Donelson, 2002; Ho, 2009; Wardhaugh, 2006). According to Mitchell \& Myles (2004: 235), "language and culture are not separate, but they are acquired together, with each providing support for the development of the other". The interwoven of language and culture is labelled with the terms linguaculture (Friedrich, 1989), language-and-culture (Liddicoat et al., 2003), languaculture (Risager, 2005), or culture-language (Papademetre \& Scarino, 2006). This suggests that language and culture should go hand in hand as the main menu of English language teaching and learning at any level of education. In other words, the import of culture in ELT is highly recommended to provide the contextualisation of the target language because the contextualisation of the target language triggers students to maximally lateralise the target language. This qualifies the message that English teachers and students of any level of education as L2 learners including VHS students should clearly understand the interwoven of culture and language (Pulverness, 2003).

\subsection{Nature of Blended Culture}

In relation to culture, a number of scholars define the word culture from different perspectives. For example, Jandt (2004:7) proposes a definition of culture as "a process of social transmission of thoughts and behaviours which are learned from birth in the family and schools over the course of generations". In addition, the word culture refers to "the totality of group of thoughts, experiences, and patterns of behaviour and its concept, and assumptions about life that guide behaviour" (Jandt, 2004:7).

The two definitions above suggest that culture is closely related to thoughts and behaviours that are practiced in the society and transmitted from one generation to another. In the same spirit, Peterson (2004) as quoted by Margana (2013) defines culture as "the totality of socially transmitted behaviour patterns, arts, beliefs, institutions, and all other products of human work and thought." In line with this definition, Mesthrie et al. (2009:28) define culture as the way of lives, a set of ideas, and a pattern of habits which are owned and shared by a group of people who live together. Tulia et al. (2003) also define culture as 'patterns of human activity and the symbolic structures that give such activity significance'. The culture may deal with knowledge, technology, arts, customs, moral systems, and many other practices and capacities created by human beings and inherited from generation to generation. This suggests that culture can be abstract and concrete things as products of human beings.

In terms of the elements of culture, Appelbaum in Margana (2009:126) classifies culture into two categories: material and immaterial culture. Material culture is defined as all physical objects created by the members of a particular society to shape their lives. This type of culture is concrete in nature. The examples of material culture include consumed goods, the places of worship, types of cuisine, offices, stores, transportation devices, technological devices, statue, artifacts, and others. Conversely, immaterial culture deals with human beings' creations that are abstract in nature. They include language, values, beliefs, customs, habits, rules, conventions, institutions, organisations, and the like.

With regard to the elements of culture, Homesfesde (1994) as cited by Jandt (2004:7) classifies culture into four elements that include symbols, rituals, values and heroes. Symbols are represented in the form of verbal and non-verbal language. Rituals refer to the socially fundamental collective practices within culture. Values refer to the perceptions towards what is good or bad, beautiful or ugly, normal or abnormal that exist in most society members of a particular culture. Heroes are real or imaginary representations of people who become models of behaviour within culture. 
Similarly, Jandt (2004:10) classifies culture into many elements that include language and gesture, personal appearance and social relationships, religion, philosophy, values, courtship, marriage, family customs, food and recreation, work and government, education and communication systems, health, transportation, government system, and economic systems. Those elements can be the content of the English materials presented in the process of English language teaching and learning. In other words, English teachers of any level of education including vocational high schools are encouraged to take the aspects of culture as the contents of the English materials (Pulverness, 2003; Margana, 2009, 2013, 20015; Sugirin et al., 2011; Sukarno, 2012) so that students are triggered to clearly see how language is activated in the social contexts of both target culture and local one (Margana, 2015). In support of this statement, Stuart \& Nocon (1996: 431499) claim that integrating target language and home culture facilitates $L 2$ learners to deal with negotiating meaning and understanding the communicative and cultural texts in which linguistic codes are activated.

In fact, the integration of culture in ELTL confers some benefits on the part of students as it could establish intercultural awareness that serves an important role in some communication practices. This statement is supported by Crozet and Liddicoat (2000) who advanced Intercultural Language Learning Approach (ILLA). This approach focuses on the incorporation of local culture and target culture which is encouraged to be applied in the process of English language teaching and learning. According to Liddicoat et al. (2003), ILLA qualifies the integration of language, culture, and learning, which is targeted to establish intercultural communicative competence (Byram, 1997). The establishment of such competence enables students to cope with different social identities and to interact with people who have multiple identities. Added to this, such intercultural competence facilitates students to mediate different cultures, to look at themselves from an "external" perspective, analyse, and adapt their own behaviours, values and beliefs (Byram \& Zarate, 1997).

In connection with the import of home culture and target culture, this paper adopted the term blended culture (BC) which refers to the import of the three types of culture: target culture, home culture, and interculture. In other words, BC is defined as the import of local culture, target culture, and interculture in the pedagogical practices. In this matter, home or local culture refers to a pattern of behaviours, values, and beliefs that the students have practiced in the social contexts that students encounter in their society. Target culture refers to the social planes that occur in inner English speaking countries that represent the actual use of language. Interculture is defined as the cultural assimilation generated from inner, outer, and expanding English speaking countries. With the import of those three types of cultures manifested in some pedagogical activities such as the development of English learning materials, learning activities, media, and assessments, students are believed to be able to establish their intercultural awareness and language sensitivity that serve an important issue in the global era. In addition, students are able to highly acquire the target language as they are engaged in the use of target language in contexts. With regard to this, it is highly recommended that BC is employed as one of the alternative models in the process of ELTL at any level of education including secondary school levels one of which is vocational high school.

To select which culture serves as the matrix culture or embedded culture, English teachers could rely on the nature of the macro-language skills, namely receptive language skills (listening and reading) and productive language skills (speaking and writing). This is called a macro-language-based accomodation. When English teachers focus on the receptive language skills, they may take the target culture as the matrix culture in the sense that the students are driven to get a lot of input texts from target culture through listening and reading practices. The home culture contexts related the topics that they present can be used as a means of reinforcing their understanding of the texts derived from the target culture. On the other hand, when English teachers of VHS focus on the development of the productive skills (speaking and writing), they may take the students' home culture contexts as the matrix culture in order to facilitate them to construct spoken texts and written texts. This is rationalised by the issue that the activation of the prior knowledge obtained from their home culture related to the topics that they are going to construct assists students to easily generate ideas. However, it is noted that the selection of home culture or target culture serving as the matrix culture should also depend on the characteristics of the students in terms of their language proficiency. This is called a student-chracteristicbased accomodation. This means that the proposed statement should be flexible in nature. For example, when English teachers realise that their students are categorised as beginning learners, the selection of home culture contexts as the matrix culture can be used to initiate the receptive macro-language skills (listening and reading).

\section{Research Methodology}

This study is categorised as descriptive qualitative research which is aimed at documenting the voices of English teachers and students of VHS concerning the use of blended culture in the process of English language teaching and learning. It documents the stance of the issues of blended culture in the English language teaching and learning 
processes at VHS in Yogyakarta. This study involved 20 English teachers and 300 students from nine VHS in Yogyakarta Special Province on voluntary bases. Three techniques: questionnaires, observations, and interviews were employed in this study. The research instruments were questionnaires, observation sheets, and interview guides. The questionnaire consisted of 20 closed-ended items concerning the respondents' understanding of the concepts of blended culture, use and benefits of blended culture, and possible difficulties in the use of blended culture as a model of English teaching at the VHS. The interview guide consisted of five structured questions that were designed to explore the three main issues above. The observation sheet was designed to verify the use of blended culture in the process of English language teaching and learning at VHS. The questionnaire and interview were conducted within the school site and the observation was done in the classroom. To back up the primary data, a video recording was employed. The collected data were analysed with the use of descriptive qualitative techniques.

\section{Research Findings and Discussion}

The study documents the following findings. First, the majority of the VHS English teachers (19 out of 20 respondents) in Yogyakarta reported a heavy focus on the presentation of the micro-language skills, one of which is grammar in isolation as the focus of their English teaching practices instead of the development of macro-language skills of listening, speaking, reading, and writing. This finding is supported by students' responses on the questionnaire. Of the 300 student cohorts, 295 students claim that their teachers tend to give an emphasis on the study of micro-language skills. Rarely do they incorporate target and local culture in the instructional processes. This finding is supported by evidence found in the teachers' lesson plans in which issues of vocabulary, grammar, and pronunciation are not incorporated in the frame of the macro-language skills as performed in the list of the indicators below.

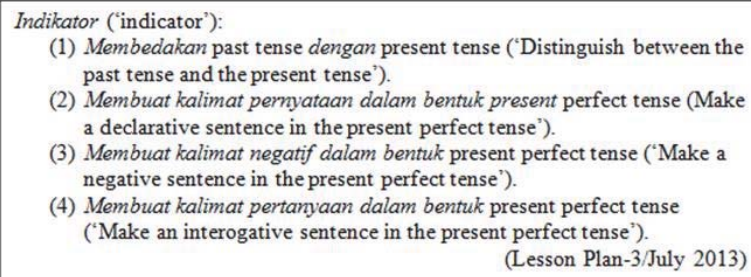

(1) Membedakan past tense dengan present tense ("Distinguish between the past tense and the present tense').

(2) Membuat kalimat pernyataan dalam bentuk present perfect tense (Make a declarative sentence in the present perfect tense').

(3) Membuat kalimat negatif dalam bentuk present perfect tense ('Make a negative sentence in the present perfect tense').

(4) Membuat kalimat pertanyaan dalam bentuk present perfect tense ('Make an interogative sentence in the present perfect tense').

(Lesson Plan-3/July 2013)

In the indicators above, heavy emphasis is put on the grammar of tenses and sentence types, asking the students to differentiate between the present and past tenses and making declarative, negative, and interrogative sentences using the present perfect tense. Such a practice should be minimised seeing that, as directed by the curriculum, grammar should be embedded in the macro-language skills. This suggests that English teachers are to develop the four macrolanguage skills of listening, speaking, reading, and writing which make use of micro-language skills in developing those four macro-language skills. The curriculum also suggests that micro-language skills should be presented implicitly in the teaching-learning processes, embedded in the study of macro-language skills. VHS students are expected to develop the ability to make sense of spoken texts (listening), to communicate in the form of spoken language (speaking), to deal with meaning making of written texts (reading), and to communicate in the form of written language (writing).

Second, findings document that teachers have not been familiar with the concepts of blended culture as one of the models of English teaching. They do not know how to design a teaching model and kit oriented to the inclusion of the blended culture in the instructional processes. They state that the use of blended culture as a model of the teaching of English in the classroom is new for them. Some teachers tend to adopt sample materials as enclosed in the curriculum to achieve the nature of the basic competence and standard competence without considering the incorporation of cultures in their teaching. They do not highlight the existence of blended culture in their teaching model. It is true that blended culture exist in their teaching activities. However, they admitted it was not intentionally designed and that it happened by chance.

It is true that I sometimes use local culture as one of the materials. For example, I often take some examples of narrative texts such Roro Jongrang, Tangkuban Perahu, and the like. I also use Cinderella as an example of target culture. But I do not realise that the incorporation of the two cultures are called blended culture. Also, sometimes I give examples of the text that I take from the target culture. But again, I do not really understand that it is a part of blended culture. (Inter-3/August/2013)

The above remark shows that something of the local culture (Roro Jongrang and Tangkuban Perahu in narrative 
texts) and something of the target culture (Cinderella) have been included in the instructional materials. However, the selection of these texts has not been intended to include blended culture in the teaching-learning process.

Third, from the questionnaire and interview data, all of English teacher cohorts had positive perspectives on the use of blended culture as a model of ELTL at VHS. They voiced that the use of blended culture in the teaching-learning process would help students to clearly understand the social planes happening in the local culture and target culture. In the same expectation, use of blended culture helps students to easily make sense of the use of language in the real contexts that directly or indirectly initiate the success of storing the English materials in a long term memory. This finding is supported by the voices of 297 or $99 \%$ out of 300 student cohorts implying that using a blended culture model in their learning would assist them to easily understand the use of English in real contexts leaving only three students who responded 'I do not know' to the option.

Fourth, all the English teachers agreed to the inclusion of blended structures in the teaching of English at VHS although they were still in doubt as to which cultural items could be incorporated into the macro-language skills. In this case, they agreed that the import of cultures in the process of ELTL could be conducted in two modes, namely macrolanguage-based accomodation and student-characteristic-based accomodation. The former means that a home culture is employed as the matrix culture when students deal with productive skill development while a target culture is applied as matrix culture when students deal with receptive skill development. The latter means that the mode relies on the students' language proficiency. For less proficient language students, the home culture is used to initiate the development of the receptive skills.

Teachers also reported some difficulties in finding materials with cultural aspects embedded. Many stated that it was hard to get learning materials that contained both cultures. Added to this, they also got confused in designing activities that accommodated local and target culture. They did not feel confident whether or not they had incorporated cultures in their teaching. So far, they disregarded the inclusion of such cultures and relied largely on the sample activities listed in the curriculum. These statements are supported by the students' voices stating that the learning activities used by their teachers did not seem to qualify for the incorporation of blended culture. In the student work sheets, they could not find items that had an indication of the use of blended culture.

On instructional media and assessment, the majority of the teachers (19 out 20 English teacher cohorts) said that they did not realise that use of blended culture in selecting and developing media and assessment to contextualise the instructional materials is of great importance for students. They felt that the assessment used in the teaching-learning processes did not accommodate problems and issues of blended culture. They stated that the inclusion of target and local culture in developing media and assessment should be highlighted as this could facilitate students to maximally acquire the target language. This statement is supported by students' voices. Of the 300 respondents, 295 or $98 \%$ student cohorts strongly agreed to the inclusion of blended culture in the instructional media and assessment because it facilitated them to actualise the use of the target language in contexts.

\section{Conclusion and Recomendation for Further Research}

Based on the findings above, it can be concluded that teachers and students have not been familiar with the use of blended culture as one of the models of ELTL at VHS. However, both cohorts agree that blended culture can be included in ELTL because such inclusion will facilitate students to maximally learn the target language. This suggests that the import of local culture, target culture, and interculture in ELTL must be facilitated. The way of importing the home culture or target culture to serve as the matrix culture could be oriented to a macro-language-based accomodation and studentcharacteristic-based accomodation. The finding that English teachers may encounter difficulties in using blended culture as a model of ELTL should be seriously taken into account by related parties. This finding also triggers efforts on the part of other researchers to conduct research and development in textbooks which include the import of home culture, target culture, and interculture. Finally, the effectiveness of the use of a blended-culture model in ELTL should be investigated in order to obtain empirical evidence that is useful for policy makers to impose the use of blended culture in ELTL in Indonesia.

\section{References}

Bachman, L F. (1990). Fundamental considerations in language testing. Oxford: Oxford University Press.

Bada, E. \& Genc, B. (2005). Culture in language learning and teaching. The Reading Matrix Vol. 5, No. 1.

Brown, D. (2007). Teaching by principles: An interactive approach to language Pedagogy. New York: Pearson.

Byram, M. (1989). Cultural studies in foreign language education. Clevedon: Multilingual Matters Ltd. 
Byram, M. (ed.). (1994a). Culture and language learning in higher education. Clevedon: Multilingual Matters Ltd.

Byram, M. \& Morgan, C. (1994b). Teaching-and-learning language-and-culture. Clevedon: Multilingual Matters Ltd.

Byram, M. (1997a). Cultural awareness' in vocabulary learning. Language Learning Journal 16. 51-57.

Byram M. (1997b). Cultural studies and foreign language teaching. In S. Bassnett (ed.). Studying British Cultures. An Introduction. London: Routledge. 53-65.

Byram, M., \& Zarate, G. (1997). Defining and assessing intercultural competence: Some principles and proposals for the European context. Language Teaching, 29, 239-243.

Canale, M \& Swain, M. (1980). Theoretical bases of communicative approaches to second language teaching and testing. Applied Linguistics, 1, 1-47.

Çelik, S. (2005). Get your face out of mine: Culture-oriented distance in EFL Context. A helpful guide for Turkish EFL teachers. TÖMER Language Journal, 128, 37-50.

Chastain, K. (1988). Developing second language skills: Theory and practice. Orlando: Harcourt Brace Jovanovic, Inc.

Crozet, C., \& Liddicoat, A.J. (2000). Teaching culture as an integrated part of language: Implications for the aims, approaches and pedagogies of language teaching. In A.J. Liddicoat \& C. Crozet (Eds.), Teaching languages, teaching cultures (pp. 1-18). Melbourne: Applied Linguistics Association of Australia.

Davis, C. W. (1996). Integrating language, culture and literature in teacher-produced ELT materials. In J.E. James (ed.), The Language Culture Connection, Singapore: SEAMEO Regional.

Fengyan, Ch., (2002). Incorporating culture into foreign language teaching Programmes, www.eltexpress.com last access 28/02/04.

Friedrich, P. (1989). Language, ideology and political economy. American Anthropologist, 91, 295-305.

Gonzalez, A. 1995. The cultural content in English as an International Auxiliary Language (EIAL): Problems and Issues". In M.L Tickoo (ed.). Language and Culture in Multilingual Societies: Viewpoints and Visions, Singapore: SEAMEO Regional Language Centre, page. 54-63. http://www.uny.ac.id/profil-uny/visi-misi, Retrieved on 13 Augustus 2011.

Hedge, T. (2008). Teaching and learning in the language classroom. New York: Oxford University Press.

Hymes, D. H. (1972). On communicative competence. In J. B. Pride and J. Holmes (Eds.), Sociolinguistics: Selected readings. Harmondsworth: Penguin.

Ho, S.T.K. (2009). Addressing culture in EFL classrooms: The challenge of shifting from a traditional to an intercultural stance. Journal of Foreign Language Teaching, vol. 6, no. 1, pp. 63-76

Jandt, F.E. (2004). An introduction to intercultural communication: Identities in a global community. California: Sage Publications, Inc.

Johnson, J. (2004). Behaviorism and second language learning. Second language acquisition (pp. 18-29). Binghamton, NY: Yale University.

Kirl, John. (2001). Language, culture, and division. Retrieved on September 30, 2009 from http://www.forthnoght.org/POLCOLS/ POLO6396.htm

Kramsch, C. (1988). The cultural discourse of foreign language textbooks. In A. Singerman (ed.), Towards a new integration of language and culture (pp. 63-68). Middlebury, VT: Northeast Conference.

Kramsch, C. (1993). Context and culture in language teaching. Oxford: Oxford University Press.

Kramsch, C., Cain, A., \& Murphy-Lejeune, E. (1996). Why should language teachers teach culture? Language, Culture and Curriculum, 9(1), 99-107.

Kramsch, C. (2001). Language and culture. Oxford: Oxford University Press.

Krasner, I. (1999). The role of culture in language teaching. Dialog on Language Instruction, 13(1-2), 79-88.

Lambropoulos, N \& Christopoulou, M. (2004). Cultural-based learning objects framework in Greek Diaspora. Journal ETחE, 29/09.

Liddicoat, A.J. (2002). Static and dynamic views of culture and intercultural language acquisition. Babel, 36(3), 4-11, 37.

Liddicoat, A.J., Papademetre, L., Scarino, A., \& Kohler, M. (2003). Report on intercultural language learning. Canberra ACT: Commonwealth of Australia.

Margana. (2009). Integrating culture into English teaching and learning process. Kajian Linguistik dan Sastra, Vol 21 No. 2 pp $123-129$.

Margana. (2012). Promoting schematic knowledge to English teachers of secondary school levels. Proceeding on International Seminar at Satyawacana University of Salatiga, pp 406-416.

Margana. (2013). Bringing students' culture in the process of English language teaching and learning. Proceeding on International conference at Muhammadiyah University of Purowkerto.

Margana. (2015). Blended culture as a model of English language teaching at secondary school levels. Proceeding on TEFLIN at University of Udayana.

Mesthrie, R.J. Swann, A.D. \& W.L. Leap. (2009). Introducing to sociolinguistics. Edinburgh: Edinburg University Press.

Mitchell, R., \& Myles, F. (2004). Second language learning theories (2nd ed.). London: Arnold.

Papademetre, L., \& Scarino, A. (2006). Teaching and learning for intercultural communication: A multi-perspective conceptual and applied journey for teachers of world culture languages (2nd ed.). Adelaide: UniSA.

Peterson, B. (2004). Cultural intelligence: A guide to working with people from other culture. New York: Intercultural Press.

Peterson, E. \& Coltrane, B. (2003). Culture in second language teaching. Eric Clearing House on Languages and Linguistics.

Pulverness, A. (2003)." Materials for cultural awareness, " In B. Tomlinson (Ed.), Developing materials for language teaching. London: Continuum, 2003, pp. 426-441.

Risager, K. (2005). Languaculture as a key concept in language and culture teaching. In H.H.A.F. Bent Preisler, S. Kjaerbeck \& K. Risager (Eds.), The consequences of mobility (pp. 185-196). Roskilde: Roskilde University. 
Siddiqie, S. A. (2011). Intercultural exposure through English language teaching: An analysis of an English language textbook in Bangladesh. Journal of Pan-pacific Association of Applied Linguistics, 15(2), 109-127.

Stuart, G. \& Nocon, H. (1996) Second culture acquisition ethnography in the foreign language classroom. The Modern Language Journal, 80 (4). 431- 499.

Sugirin et al. (2011). A study of cultural integration in junior high school text-books. Litera, vol. 10. No:2, 235-246.

Sukarno. (2012). Integrating local culture in teaching English as a foreign language for character building. Jurnal Pendidikan Karakter, Year I, No 2.

Sysoyev, P. V. \& Donelson L. R. (2002). Teaching cultural identity through modern language: Discourse as a marker of an individual's cultural identity. Online documents at URL http://www.actr.org/JER/issue4/11.htm, Retrieved on April 10, 2014.

Trumbull, E. \& Rothstein-Fish, C. (2009). Cultures in harmony. In M. Scherer. (ed.), Engaging the Whole Child: Reflection on best Practices in Learning, Teaching, and Leadership, Alexandria Virginia: ASCD (the association for supervision and curriculum development), Page. 321-328.

Tulia, C. Z. C. et al. (2003). Integrating the coffee culture with the teaching of English. PROFILE Vol. 11, No. 2, Pages 27-42.

Wardhaugh R. (2006). An introduction to sociolinguistics. Massachusetts: Blackwell Publishers.

Williams, G. (2011). ESL teaching: How language and culture are interdependent. Language Study, November. 